\title{
IMPORTANT ASPECTS OF MIDWIFERY
}

\author{
by
}

Estelle Barnett RN, RM, RST

(Former Midwifery Tutor, Addington Hospital)

\section{OPSOMMING}

Belangrike aspekte van verloskunde word beklemtoon, met die klem op die dringende rol van die vroedvrou gedurende swangerskap, baring en gedurende die puerperium. As 'n praktisyn in haar eie reg, is die vroedvrou in staat om die ouers te onderrig en ' $n$ gevoel van vertroue daar te stel. Deur te weet wat as normaal beskou word, kan die vroedvrou vroegtydig abnormaliteite diagnoseer en dus 'n suksesvolle swangerskap, baring en puerperium, verseker. Die geboorte van 'n baba is maar een aspek in die algehele handhawing met betrekking tot die bekendstelling van 'n nuwe lid tot die familie, asook die gemeenskap. Dit is die "komprehensiewe vroedvrousorg"' soos gestipuleer in hierdie artikel, wat die maksimum gesondheid, geluk en sekuriteit van hierdie nuwe lid en die res van die gesin as 'n geheel verseker.

\section{HISTORICAL BACKGROUND} Introduction

$\mathbf{T}_{\mathrm{a}}^{\mathrm{s}}$ he art of midwifery must be one of the oldest of acquired skills. In prehistoric times, the more experienced women assisted and comforted their younger relatives during parturition. There are scattered references to midwives in ancient literature, including the Bible. In Genesis 35:17 we learn that Rachel's death was the result of "hard labour". One should congratulate the midwife who delivered Sarah of a son at the age of 90 years - Genesis 17:17. Midwifery stagnated during the Middle Ages due, partly to the ignorance of the midwives as well as to a lack of knowledge of human anatomy coupled with the accepted teaching of the ancients, which was regarded as the ultimate authority. Great advances in the art and science of midwifery have occurred since the Middle Ages, amounting to a revolution in thought and practice. Less than 100 years ago, in 1898, in W.S. Playfair's "Science and Practice of Midwifery" no mention was made of any form of antenatal examination or even of the testing of urine for albumin. Times have indeed changed - today the whole concept of maternal and child care would be quite unrecognisable to a Victorian midwife. We have also accepted the male midwife into our midst.

THE MULTI-FACETTED ROLE OF THE MIDWIFE

1. She is primarily a health educator. Midwifery is so essentially an integral part of preventive and promotive health care and the midwife is able to manipulate situations so that people regard their "needs" as their "wants".

2. As a practitioner in her own right, she is a diagnostician and by her accurate observations, she is able to prevent complications and by prompt action in an emergency can save the life of mother and baby.
3. As a "mother figure" her attitude is always empathetic, supportive and encouraging thus she is able to instil confidence in her patients, obtaining their maximum co-operation. Not only must she be knowledgeable but she must be able to communicate and be able to "listen". She must always be tolerant, understanding and kind. Today, when the young mother is presented with a plethora of information, sometimes quite erroneous, gained from glossy magazines, of which she is an avid reader, the midwife should be able to counteract much of this information.

4. She should be able to treat the mother, at all times, as a unique individual, who has her own problems, culture and fears. The midwife must respect the personal dignity of the mother and must never impart a feeling of inferiority in people or scoff at their beliefs.

5. The midwife should always consider herself as a teacher and the practical nature of her role should never be forgotten.

FEAR: Fear of the unknown, of labour, of pain, of responsibility, of producing an abnormal child and the fear of responsibility are very real fears affecting most pregnant women. Women themselves tend to keep many of these age-old fears alive. The fear-pain-tension syndrome is known to affect the outcome of labour. The midwife, in her multi-facetted role must inculcate a feeling of confidence in her patient as well as the proper perspective with regard to the risk she is taking.

\section{How to alleviate fear:}

1. Education and explanation in simple, understandable language of the process of pregnancy and parturition. 
2. Breathing exercises and relaxation techniques: The mother learns and practices assiduously the correct breathing techniques so that, when in labour, she is able to control her breathing pattern. Irrespective of what method of relaxation exercises are taught, all aim at the same result - concentration on individual breathing patterns, the rhythm thereof giving mental release.

\section{ROLE OF THE FATHER}

Parentcraft classes are invaluable and explanation to the father has a beneficial effect. The birth of a baby is a "shared responsibility" and with knowledge and understanding gained from the classes, the father soon realises how important he is in helping provide emotional support for his wife. His fears are also assuaged. Some husbands come as enthusiastic participants to the classes, but, just as often they come very reluctantly. Very often the reluctant husband becomes one of the most committed of men!!!!

\section{AVAILABILITY OF ANALGESIC DRUGS}

It is imperative that patients be told that analgesic drugs are available if the mother's pain threshold is low. There is no need for any woman to suffer excruciating pain. Similarly they should know that the breathing techniques practised by the mother will considerably alleviate the pain felt.

\section{PHYSICAL HEALTH}

Antenatal exercises have a beneficial effect on the woman's respiratory, circulatory, and muscular systems, besides imparting a feeling of euphoria. Exercises classes serve as a useful adjunct to group therapy. The foetal circulation and well-being is also enhanced.

\section{NUTRITION}

Cognisance must always be taken of the following, whenever advice on diet is given:

Socio-economic, cultural and intellectual factors.

Individuality of the patients - personal likes and dislikes.

Availability of food and of refrigeration.

Method of preparation and cooking.

The midwife should emphasise the effect of poor nutrition on the unborn child.

Cigarette Smoking and the effect of taking medicines not specificially ordered:

The dangers cannot be over-emphasised.

\section{BREAST FEEDING}

Regrettably, "lip service" is paid to this most important aspect of midwifery all too often. Successful breast feeding can be established if the midwife believes in the efficacy of the "product" she is "selling" and if she gives the proper advice to the patient about the care of breasts and nipples.

The most important advantages of breast feeding are: Bonding is established between the mother and her infant.
- There is a decreased risk of infection by viruses, e.g. Poliomyelitis and by the Bacillus Coli and Protozoa. Colostrum and breast milk contain Immunoglobulins $A, G$ and $M$ and there is also the presence of the Lactobacillus Bifidus.

- Allergies such as Eczema and Asthma occur less frequently in breast fed infants.

- Metabolic diseases, e.g. Rickets occur less frequently as well.

\section{Care of breasts and nipples:}

The use of soap and water daily, and drying with a rough towel is necessary. The nipples should be gently rolled between finger and thumb. A cream may be applied to the skin of the areola if it is dry. Flat and/or inverted nipples should be treated appropriately. In order to keep the lactiferous ducts patent, the mother should be shown how to express the fluid from the breasts from about the 26th week of pregnancy - it is necessary for the technique to be properly understood and also that this must only be done for 1-2-minutes on each breast twice a day. Vigorous friction using nail-brushes or using methylated spirits must be avoided.

Brassiere: If brassieres are worn, they should be wellsupporting and of a reputable make. They should, preferably, be of cotton, with wide straps and should not flatten the nipples.

Avoidance of guilt-complex: It is imperative that the mother be constantly reassured that she must not consider herself a failure if she is not able to breast feed her baby or if she does not want to do so, for various reasons.

\section{UNTOWARD SIGNS AND SYMPTOMS OCCURING DURING PREGNANCY:}

It is necessary for both parents to know how to recognise Pre-Eclampsia and Antepartum Haemorrhage and for them to know what action to take. They should also know that an increased frequency of micturition is quite normal during pregnancy, but that any dysuria, burning on micturition and a diminishing urinary output are abnormal. Serious complications can thus be prevented.

\section{ANTENATAL VISIT TO LABOUR WARD}

There can surely be nothing more frightening for a woman in labour to be confronted with machines and gadgets from which staccato noises are emanating, when she arrives at a busy labour ward. This fear can be obviated by simply, wherever and whenever possible, showing parents the labour ward and its varied equipment, at some stage antenatally. Unfortunately, the machines found in the labour ward are often accepted as "commonplace" by nursing and medical staff.

The "language" of labour should be explained to both parents to avoid confusion. "Epidural Block", "Induction of Labour", "Caesarean Section", "Episiotomy”, “Breech delivery", and "Instrumental 
delivery" are procedures that tend to cause concern to patients and explanations should be simple and truthful. (Articles appearing in glossy magazines tend to confuse parents).

\section{LABOUR}

"How" labour commences, "how" to time uterine contractions, "when" to come to hospital and "when" to contact the midwife or doctor, "where" to come, "what" the telephone number of the institution is, and "what" to bring with them, should be carefully explained to both parents and the midwife should make sure that everything said is clearly understood.

During labour, the reassurance and encouragement of the mother is essential. There should be a reinforcement of breathing and relaxation techniques learnt earlier. The "how" and "when" to "bear-down" should also be known. Instructions should be given by one person only who, in spite of possible adverse conditions, remains calm, confident and capable at all times. The presence of the father in the labour ward helps reassure and support the mother. The progress of labour should be explained to the parents in simple language.

\section{Recognition of normal labour}

By diligent observation of both maternal and foetal conditions, the midwife should be able to detect any deviation from normal and thus obtain medical aid early. She should know what to do if an emergency situation arises. "Be prepared" should be her motto. Accurate recording of her observations cannot be overestimated.

\section{Position of the mother}

The patient should be either in the lateral position or the upright sitting position during labour. It has been shown that these positions lessen aortic-caval compression, decrease levels of pain and tension and reduce oxygen tension. They are also the best position for the baby.

\section{Neonatal resuscitation}

The indiscriminate suctioning of the infant should not be practised - suctioning is of value when the liquor is not clear. It is imperative to clear the airpassages of meconium and blood under direct vision, otherwise the suctioning of the infant is controversial. The neutral or head-up position may be of greater benefit to the asphyxiated infant, because the liquor in the foetal lungs does not drain out by gravity from the "head down" position, but returned to the general circulation via the lymphatics. (Ref. 1).

\section{Physical appearance of the infant at birth}

"Forewarned is forearmed", therefore parents should be prepared about the presence of vernix caseosa, blood on the baby as well as the possible presence of a Caput Succedaneum and the elongated head associated with moulding. Also that it is normal for the presence of slight cyanosis. Explanations should be given. A "frightening experience" can thus be avoided. In the event of abnormality, the midwife should use her discretion.

\section{Identification of baby}

The parents should be reassured that "mixing-up" of babies does not occur and the method of identification carefully explained. The terms "boy/girl" should be used instead of "male/female".

\section{BONDING}

This very important facet of midwifery is established at birth when the parents are advised to handle and to fondle the baby, with the mother putting the baby to the breast immediately after birth and establishing "eye contact." Attachment is thus begun and early parentchild relationship should proceed without crisis. The midwife is in a unique position to promote optimal family development. The mother, by trial and error, develops a sensitivity in assessing the baby's needs and she modifies and expands her intervention to more successfully comfort and entertain the infant. During feeding she fondles the infant and frequently looks at $\mathrm{him} /$ her "face to face" which is the most effective stimulus for eliciting visual fixation and smiling. "Rooming-in" should be practised whenever possible. Not only is bonding effectively established but the mother becomes more confident in the handling of her infant.

\section{PREVENTION OF CHILD ABUSE}

In the article, "Die gebeukte kind" (Curationis March 1980), Professor M. C. van Huyssteen showed how the midwife can make a significant contribution towards the prevention of child abuse. The predominant factors responsible for child abuse, the midwife's awareness of the patients at risk, the establishment of mother-child bonding and the inherent danger associated with the separation of the baby from the mother are factors that need re-iteration.

\section{BONDING APPLICABLE SPECIFICALLY TO PRE-TERM AND TO INFANTS NEEDING INTENSIVE CARE}

Whenever the infant is nursed in an incubator, the parents should be encouraged to visit the infant frequently and should not only "look" at the infant, but should touch, caress and "talk" to the infant. Wherever possible, the mother should be shown how and encouraged to tube-feed the infant under the midwife's supervision. Bonding and breast milk supply will be considerably improved.

\section{ADOPTION OF BABIES}

Adoption procedures were outlined in the March 1980 issue of Curationis. The importance of the combined role of social worker and nurse is re-iterated. The mid- 
wife should, however, remember that her observations of the infant's condition, behaviour and feeding pattern are most necessary, and that the slightest deviation from normal must be recognised and reported. As the midwife is the surrogate mother, bonding should be between the baby and a very limited number of staff (at the most three midwives). Wherever possible, the same midwife should be responsible for the care, feeding and handling of the baby. Quite of ten the infant for adoption is in the midwife's care for some time. Confidentiality should be respected.

The biological mother should be handled with tact and sympathy during her pregnancy labour and peurperium with the midwife working in close liaison with the social worker. "Handing over" of the baby to the adoptive parents should take place privately. The personal feelings of the adoptive parents should be respected. Wherever possible, some instruction in parentcraft should be given them.

\section{GENETIC DISORDERS}

Much attention and publicity has recently been given this important aspect of midwifery. The midwife should be aware of what genetic services are available and what the indications are for referral to a genetic clinic, for sex chromatin counts, for chromosomal studies, for amnioncentesis and for metabolic screening. (Referral to the Genetic Services Bulletin no. 1 of 1979, published by the Department of Health is necessary). At all times the midwife should reassure and support the parents.

\section{LEGISLATION}

The midwife should be able to advise the parents about the registration of the birth and to inform them where and when to do this, in terms of the relevant legislation.

\section{POST-NATAL CARE}

Post-natal depression affects some women more than others, particularly the sensitive, artistic woman. Explanation to both parents during the antenatal period about the possibility of this occurring, and the reason therefor, should be given to avoid fear later. The fact that it is a natural phenomenon should be mentioned.

Post-natal exercises are necessary in order to help in the return of the reproductive organs to normal, assist drainage of lochia and help in the establishment of lactation. The midwife should encourage the mother to do these exercises.

Control of post-partum haemorrhage: Bleeding can be controlled by the mother if she is shown how to massage the uterine fundus if she is bleeding and aid is not immediately available.

Vulval toilet and care of the perineum: The mother should know exactly how to carry out these procedures. Explanation of the "how" and "why" should preferably be given during the antenatal period.

\section{MOTHERCRAFT}

Bathing, handling and dressing of the baby

The mother should be taught how to carry out these procedures and the midwife should ensure that the mother is fully confident before she is discharged from hospital. The mother should know what is normal and should be constantly reassured and encouraged. Cognisance of what facilities are available at home must be taken and information tailored accordingly. Midwives, at times, tend to lose sight of the fact that not all homes have running water, stainless steel baths and basins or special liquid soap.

\section{Care of the umbilical cord}

In view of the fact that patients are discharged very early, it is imperative that the mother knows the correct technique in the care of the umbilical cord to avoid serious complications later. The reason why abdominal binders are not advocated is explained.

\section{Observation of stools}

Mothers, very often, tend to have a "bowel complex", therefore it is necessary for midwives to reassure the mother that it is not necessary for a breast fed baby to have a stool daily and that it is quite normal for them not to have a stool for up to a week or longer. The "why" is explained. The mother should also know that the passage of one or two green stools, providing that the general condition of the baby is unchanged, is also considered normal.

\section{Feeding}

Whether the infant is fed on demand or by fixed schedule depends on both mother and baby, but the mother should know that the baby should never be awakened for a feed.

\section{Artificial feeding}

If the mother is not able to breast feed her baby, she should know exactly how to prepare the baby's feed. Using equipment that is available at home, the mother is shown how and should undertake the preparation of the feed. She should be warned not to "chop and change" the feed without professional advice. Gastro-intestinal disorders can be avoided.

\section{Introduction of solids}

The mother should be advised not to introduce solids into her baby's diet before the infant is at least 4 months of age. She should know that fat babies are not necessarily healthy babies and she should know what mass the baby should "put on". Midwives should be aware of the fact that the infant's urinary system cannot adequately deal with a high solute load until the child is about 4 months of age.

\section{Defective Hearing}

By teaching the mother how to carry out simple auditory tests at $8-9$ months of age, the midwife will help in the early diagnosis of defects of hearing and thus ensure prompt treatment.

\section{Immunisation of infants}

Parents should know of the benefits of immunisation and what the legal implications are and they should know the "when" and "where" they should take the child.

\section{Family Planning education}

Must not be overlooked as one of the most important aspects of midwifery and the midwife must adequately fulfill her role in this respect. 


\section{Control of bodily functions}

The midwife can influence the mother's approach to this process by advising her that, in spite of what she may hear to the contrary, the child cannot be trained to control his/her bodily functions until they can stand on their own, because the tracts of the spinal cord are only myelinated to the anal level by then. If attempts are made before this the child is being "conditioned" and not "trained" with the result that there is frustration and dismay later when the process "breaks down." The most suitable age is between 15 and 18 months of age.

\section{CONCLUSION}

Important aspects of midwifery have been outlined with the emphasis on the role of the midwife during the management of pregnancy, labour and the puerperium. Courses in advanced midwifery are available, today, for the midwife who practices in a rural area, where medical assistance is virtually non-existent. These courses equip her to carry out procedures, normally the prerogative of the Doctor, in order to lessen mortality and morbidity. This is a tremendous extension of her important role. But . . . what about the urban midwife, and her role with regard to the urban patient. Has the time not come for the midwife, once again, to more adequately fulfill her role as a practitioner in her own right. With the escalating costs of hospitalisation, is it not more feasible for the mother, if she so wishes, to be delivered in her own home. Without electronic aid, the midwife, by using her eyes, her ears, her hands and above all, her skills, could successfully deliver women of selected categories.
The category of patient would be limited to: (1) Multiparous women (Para 2 and Para 3) who have a good past and present obstetric history. (ii) The environment would be suitable and the necessary equipment would be readily available. (iii) Close proximity to medical assistance or hospital, in case of emergency. (iv) Transport would be easily available.

The advantages of domiciliary midwifery are manifold: they include the following: Family bonding is enhanced; sibling jealousy is reduced; freedom from worry, economic pressures and infection; familiar environment and more successful breast feeding.

Today, in 1980, on the South African urban scene, "operative obstetrics" does appear to predominate, and the infant, more often than not, is delivered by the Doctor in hospital. The delivery of the infant is but one focal point in the overall management involved in the introduction of a new member of the family and to society, It is the total midwifery care, as outlined in this article, that will ensure the maximum health, happiness and security of this newest member, as well as the family as a whole.

\footnotetext{
References

1. Lectures given to a multi-disciplinary audience at a Perinatalogy symposium organised by the Obstetric, Paediatric and Anaesthetic departments of the University of Natal in Durban, in May 1979.

2. Curationis - March 1980.

3. Hall, J.E. \& Weaver, B.B. 1974: Nursing families in crisis Philadelphia: Lippincolt Co.

4. Radcliffe, W. 1967: Milestones in midwifery London: John Wright and Sons.
} 